\title{
Implementation of Anti-Corruption Policy in the Digital Economy
}

\author{
Oksana Trotsenko*, Irina Soshnikova, and Yaroslav Semenov \\ Ural State University of Economics, 620144 Yekaterinburg, Russia
}

\begin{abstract}
This article examines the problem of developing legislative measures aimed at combating corruption in the higher education system. The relevance of the topic chosen by the authors is emphasized by the massiveness of research conducted in recent years by domestic and foreign scientists aimed at studying the factors of the appearance of corruption, its impact on the rule of law, as well as the experience of other countries in the fight against corruption in the higher education system. The author's position, formulated at the end of the study, is based on the analysis of statistical data derived by the International Non-Governmental Organization "Transparency International" for 2019 and foreign experience in comparison with the domestic one.
\end{abstract}

\section{Introduction}

Corruption as a social and legal phenomenon permeates all spheres of the society. The progress of this phenomenon in the spiritual sphere causes particular concern. First of all, we are talking about two subsystems of this area of stable relationships between social subjects: science and education, in terms of its highest level. There is no need to think long about the harmfulness of such subject-oriented corruption manifestations. The predicted result is expressing in the consciousness of the masses the false value orientations, which ultimately lead to distance from the state. The most vulnerable in this sense is young generation, whose worldview in the process of comprehending science is improving and becoming professional.

It is important to understand that the situation in a higher educational institution, in conjunction with the moral and ethical image of the leadership and the teaching staff, predetermines how a yesterday's student will be aware of the basic laws of the development of the surrounding reality, whether he will be able to adequately assess events and the sociopolitical situation in the country and the world, to perceive trends and patterns of its development, as well as to carry out moral self-orientation in the field of meanings and values. And the point is not even that in the process of studying at a higher educational institution, an individual student may personally face corruption, and negative trends can also affect him as an outside observer of the outrage that is taking place.

At the same time, it is not entirely correct to think from the perspective of the influence of corruption only in relation to today's students, on the basis of which it is not entirely cor-

\footnotetext{
${ }^{*}$ Corresponding author: trocenko.o@mail.ru
} 
rect to put forward an assumption about the future (or even existing) disunity of civil society. It is necessary to consider the problem from the other side. Such corrupt manifestations cast doubt on the ability of higher educational institutions to train highly qualified specialists, and the quality of education is seen as illusory. This not only does not contribute to the development of this or that state, but hinders it as such.

\section{Materials and methods}

The problem raised by the authors has acquired a global character in recent years. A number of domestic and foreign scientists devote their scientific works to the study of the factors of the emergence of corruption, its influence on the rule of law, to the study of foreign experience in combating dishonesty and dishonesty in the higher education system. For example, the American scientist Liz Reisberg rightly notes that academic corruption is the result, firstly, of an unsuccessfully designed system of checks and balances in the management segment, and secondly, a lack of understanding among students and employees of the norms of ethical behavior, and thirdly, the tendency of people resolve difficult situations in a commercial way [1, p. 68 - 71]. Dutch scientist O. Guss and German scientist A. Keidel analyzed the world practice of using the concept of "open government" in public administration in the field of education and science. In their study, the authors concluded that in countries with low levels of corruption, "open government" does not meet the founding goals (the goal is to provide inclusive, fair and quality education for all through partnerships between stakeholders in the education system), in contrast to countries with systemically high level. For greater efficiency, this mechanism of interaction between the government and civil society should follow the principles of transparency, accountability and citizen involvement [2]. Russian scientists V.M. Aliev and N.N. Solovykh, believe that in order to prevent corruption in educational institutions, it is required to create certain sources of "forming public opinion" (newspapers, magazines, publicly available electronic resources), designed to assist state authorities in the process of identifying corruption crimes [3, p. 49 - 50]. In addition, international and some national organizations have made a significant contribution to the methodology of combating corruption in the field of higher education. For example, with the support of the International Institute for Educational Planning (IIEP-UNESCO), the information portal ETICO [4] was created, aimed at combating corruption in the education system around the world. On the presented web resource, the developers combine corruption news, various statistical materials, scientific and reference publications on the relevant narrow topics. The published typology of corrupt behavior, which groups acts into the following types, is of undoubted importance for the development of preventive measures: misuse of budgetary appropriations; fraudulent public procurement; fraud in the field of employment and employment of personnel; violation of the procedure for passing exams (passing intermediate or final attestation), including violation of the procedure for passing candidate and doctoral examinations, defense of dissertations for an academic degree; non-compliance with the legally established requirements for licensing and accreditation of an educational institution; violations in the field of information security; favoritism [5].

As for national organizations, it is worth highlighting the state body of the Islamic Republic of Pakistan - the Commission on Higher Education, which has introduced into world practice the foundations for preventing illegal borrowing in written works of students, researchers, teachers. Note that this country has a somewhat broader understanding of academic corruption, even identified with plagiarism. With the direct participation of higher education institutions, the aforementioned authority issued an explanatory act "A little book about plagiarism: what is it and how to avoid it?" and a regulatory act "State policy against plagiarism". The explanatory act defines the concept of "plagiarism" as a special form of 
deception, an intellectual crime, provides reasons why plagiarism should be abandoned and how to avoid it [6]. The document of a normative nature provides for a fine for plagiarism admitted in written work, assigned taking into account the severity, recurrence, status of a scientist or research worker. In addition to the monetary penalty, a scientist or research worker is included in the "Black List" with the subsequent prohibition of employment in any scientific organization [7].

Thus, in world practice, the phenomenon of corruption is more studied, and many mechanisms of anti-corruption policy have been working for several years, bringing a great success.

\section{Results and discussion}

Further, within the framework of the topic of this article, we will consider the results of the research conducted in 2019 by the international non-governmental organization "Transparency International" on corruption in the public administration sector. The study included indicators of 180 countries, subsequently ranked on a scale from 0 (high corruption) to 100 (low corruption) points [8]. The Kingdom of Denmark ranks first among the least corrupt countries (87 points). The anti-corruption policy of this country is based on public rejection and zero tolerance for such a phenomenon as corruption. Each member of the Government, in accordance with the Law on Corruption adopted in 2002, is obliged to submit a report on his property and income [9]. Information about all operations is publicly available, and every citizen of the Kingdom of Denmark can apply to law enforcement agencies to report a crime, including anonymously. Business and government work together in this area. Several organizations have been created in the country that provide assistance in the anticorruption fight and cultivate anti-corruption (Trade Council of the Kingdom of Denmark, Danish International Development Agency - DANIDA). Thanks to the policy of "zero tolerance" to corruption, this state of affairs has been established in all spheres of society, including education. Citizens comply with the law not only because of "public rejection", but also because of harsh sanctions, which are changing towards the worse, as well as fear of a ruined business reputation, thanks to which a person involved in corruption loses not only his position and work, but the possibility of full cooperation with other people.

Another of the least corrupt countries is the Republic of Singapore ( 85 points). In the country, anti-corruption policy is aimed at minimizing and eradicating conditions for the growth of corruption. All actions of officials are regulated, but at the same time, bureaucratic procedures are simplified. The country has created a special Bureau for Investigation of Corruption Cases, considering complaints from citizens about corruption and investigating cases of negligence and negligence of civil servants, and also checks institutions [10, p. 122]. To prevent officials from being tempted to take the offered bribe, their salaries were increased, at the same time, the economic sanction for corrupt acts or refusal to cooperate in the investigation of such cases was tightened [11]. All this concerns not only the "lowest" and "highest" levels of corruption in education, but the entire state apparatus as a whole. The Republic of Singapore has high ethical standards of conduct for people in positions that oblige them to observe them, as well as rigorous supervision of their implementation. The country has a great respect for the law, based on the fear of huge fines and corporal punishment, up to and including the death penalty. Such measures are considered quite justified, if we recall what this country was like before the government of Lee Kuan Yew, one of the most corrupt countries in Asia. Officials took advantage of their position because of the difference in income between the public sector and business, which also flourished various corruption schemes. What the country has become now can really be called an "economic miracle". Since childhood, people in Singapore have become accustomed to a large number of prohibitions and do not knowingly violate them, knowing that misconduct will 
necessarily be punished. Ethical norms and legal literacy have become an integral part of their lives, fostering the mentality of this nation. The Anti-Corruption Strategy in the Kingdom of Sweden ( 85 points) is built on the observance of ethical standards. From childhood, subjects are brought up to be honest in achieving success, hard work, frugality and responsibility. The absence of bribes and other corrupt activities is taken for granted, otherwise causes resentment and rejection. Much propaganda is carried out by the mass media and the Church, a great contribution to it is also made by the anti-corruption public association "Institute against Bribery" [12, p. 67]. The criminal penalty is not as harsh as in other countries - the maximum term of imprisonment for abuse of office is 6 years. Any such crime is immediately covered by the media. In the Kingdom of Sweden, public censure and loss of business reputation represent a great sanction for a corrupt official.

In the United States of America (69 points), the fight against corruption is given a great deal of attention, with an emphasis on responsibility for corruption and its legislative interpretation, which is undoubtedly broader than in other countries. Also, in the United States of America, the same experience is applied as in the Russian Federation with respect to gifts for civil servants, but at the same time an interesting mechanism of "collective responsibility" and lack of special status is applied. If someone is caught on a bribe or other corrupt act, not only him but also colleagues, who are subject to various sanctions, up to and including dismissal, is at risk [9]. Thanks to the totality of all of the above, citizens form a public sense of justice, thanks to which they actively contribute to solving this type of crime.

Even the People's Republic of China (46 points, separately singled out Hong Kong - 76 points), speaking about the eradication of corruption in higher education, is based in its preventive measures precisely on the moral and ethical consciousness of teachers, students and party committees. Briefly, measures to combat corruption in the People's Republic of China can be expressed in two theses: moral education and severe punishment [13].

An analysis of statistical data led the authors to the conclusion that one of the most effective methods of fighting corruption in general and in the higher education system in particular is public rejection of this phenomenon and the fear of punishment for its commission, as well as supervision and consistency in the fight against this phenomenon.

In Russian Federation, to combat corruption in the field of higher education, the Unified State Exam (hereinafter - the Unified State Exam) was introduced in 2009 as a nonalternative way of final exams. However, his mechanisms were not perfect: the answers could still be bought on the Internet. According to Rosobrnadzor data for 2009, 25\% of 100 -point works did not confirm these results, therefore, if corruption at the initial stages was reduced, then not much [14]. Now the procedure for holding the exam is complicated, which really significantly reduces the level of corruption when entering higher educational institutions, but the positive dynamics has led to new ways of circumvention. Among them are admission on entrance examinations conducted by the higher educational institutions themselves, as well as the system of student portfolios, in which the presence of a diploma of the winner of the Olympiad held by a particular educational institution actually ensures admission to this institution [15] Unlike the USE, these mechanisms are poorly controlled, hence corruption is a very common phenomenon.

Another good decision was the introduction of a ranking of higher education institutions. The competitive spirit is always stimulating; this allowed many universities from the periphery to compete on equal terms with the capital's higher educational institutions. The emerging trend has led to an increase in the quality of education, but at the same time and equally to the progress of corruption crimes at the "highest" level.

At the local level, in some higher education institutions, the BlackBox system has recently appeared - students leave messages anonymously, faced with corruption in the learning process [16]. Such a mechanism really helps to expose teachers who take bribes from 
students, so it is quite appropriate to talk about the work of this system. At the same time, some institutions have come up with a way to bypass such anonymous messages. The instructor communicates the "price" of the grade or credit to one of the verified students, who in turn disseminates this information to other students. Thus, the student cannot claim that the teacher personally provided him with the "price list". The fact that he received this information from another student has no grounds, because when proving guilt it will not be possible to assert exactly the employee's guilt, since it would be quite logical to deny that he provided such information to the student. Bottom line: a corrupt official will remain unpunished.

\section{Conclusion}

Based on the foregoing, much is being done in the Russian Federation to prevent and suppress corruption in the field of higher education, but Russian entrepreneurial spirit interferes with the planned implementation of anti-corruption programs. We cannot fully rely on the experience of foreign countries, due to the fact that, unlike the Russian Federation, other countries occupy a less extensive territory, therefore, the control system is more focused on identifying, suppressing and preventing offenses, plus it is necessary to take into account other historical traditions and mentality population of a particular state. We can only rely on some of the best practices for our country. However, any mechanism in the Russian Federation can be bypassed due to the peculiarities of the personality of Russians - the famous Russian ingenuity. According to a survey conducted by the National Education Resources Foundation in 2018, the following data were obtained: 8 out of 10 citizens consider it impossible to defeat corruption, since a third of the respondents would not turn to law enforcement agencies if they had witnessed corruption offenses [17]. Moreover, every fourth respondent perceives corruption as a traditional phenomenon in society. In our country, abuse of rights is too widespread, there is no respect for the law and fear of public censure, as is cultivated in the Republic of Singapore, the Kingdoms of Denmark and Sweden.

Possible measures to suppress corruption in the field of higher education, according to the Federal Law "On Combating Corruption", include: conducting a unified state policy in the field of combating corruption; establishing a mechanism for cooperation between government bodies and citizens and civil society institutions on anti-corruption policy; adoption of legislative and other measures to form an intolerant attitude towards corruption; improving the system of state bodies and establishing public control over their activities, as well as specifying the powers of state institutions and their employees; creation of a unified system of prohibitions, restrictions and permissions for each specific field of activity; ensuring the openness of the activities of state bodies and institutions for citizens and ensuring the independence of the media [18].

Of the special measures that have had a positive result in other countries, we can single out: change in personnel policy, both in relation to civil servants and other structures; internal and external audits of organizations by independent competent authorities; providing a mechanism to assist citizens and law enforcement agencies while maintaining anonymity, as well as cultivating intolerance towards corruption in the legal consciousness of Russians.

However, one of the most important measures of anti-corruption policy is to change the consciousness of citizens. Indeed, this experience should be adopted from foreign states. If corruption is considered a grave crime in society, and not an everyday occurrence, and if the offender is afraid not only of criminal punishment for the act, but also of public censure, then only then it will be possible to say with confidence that the Russian Federation is a free country from corruption. 


\section{References}

1. Global perspectives on higher education, 46, 181, 22140859 (2020)

2. O. Huss, O. Keudel, Open government in education: clarifying concepts and mapping initiatives, The UNESCO Digital Library

3. V.M. Aliev, N.N. Solovykh, Russian investigator, 4, 46 (2019)

4. Web-based resource platform focused on solving problems of ethics and corruption in education, Official website of the International Institute for Educational Planning (IIEP-UNESCO), https://etico.iiep.unesco.org/

5. Corruption risks in education, Official website of the International Institute for Educational Planning (IIEP-UNESCO), https://etico.iiep.unesco.org/

6. The Little Book of Plagiarism, Official website of the Commission on Higher Education of the Islamic Republic of Pakistan, https://hec.gov.pk/

7. Plagiarism Policy, Official website of the Commission on Higher Education of the Islamic Republic of Pakistan, https://hec.gov.pk/

8. Corruption Perceptions Index, Official website of the International Non-Governmental Organization Transparency International, https://www.transparency.org/

9. World experience in fighting corruption and Russian realities, Center for Political Information (2018) http://polit-info.ru/

10. M.S. Haricheva, Bulletin of the Kaliningrad Law Institute of the Ministry of Internal Affairs of Russia, 3(25), 121 (2011)

11. Arseny Sirotin, Singapore's Anti-Corruption Experience: Treating Contagious Greed, Institute for High Communitarianism, https:/communitarian.ru/

12. F.F. Shurygin, Young scientist, 34, 66 (2018)

13. Li Xu, Improving the Anti-Corruption Mechanism in Higher Education Institutions in China in New Conditions, Governance, 3 (2019)

14. A quarter of 100-point works on the exam have not been rechecked, RIA Novosti, https://ria.ru/

15. Olympic failure, Higher School of Economics - National Research University, https://www.hse.ru/

16. Black box, Non-profit organization «Anti-Corruption Foundation», https://blackbox.fbk.info/

17. Corruption in numbers, Foundation for National Education Resources, https://nro.center/

18. Anti-corruption: Federal Law of 25.12.2008 N 273-FZ (24.04.2020), Russian news paper, 266, 30.12.2008 